\title{
Pengaruh Penerapan Metode Eksperimen Menggunakan Phet Simulation Terhadap Kemampuan Berpikir Kritis dan Hasil Belajar Ditinjau dari Pengetahuan Awal Siswa SMP/MTs
}

\author{
Wiravanjava ${ }^{1}$ \\ Program Studi S2 Pendidikan Fisika, Pascasarjana Universitas Ahmad Dahlan, \\ Jl. Pramuka 42, Sidikan, Yogyakarta 55161 \\ Email : vanjavawira@gmail.com
}

\begin{abstract}
This study aims to determine the effect of the experimental method using PhET simulation on the ability of critical thinking and learning outcomes in review from the initial knowledge of students of class VIII MTSN Maguwoharjo Sleman. The population used is class VIII which is divided into 4 classes of parallel namely class VIII A, VIII B, VIII C, VIII D. Sampling is done randomly, so that obtained class VIII B as control class and class VIII $C$ as experimental class treated with experimental method using PhET simulation. Technique of data retrieval is done by giving pretest to know early knowledge of student. Then do different learning, then students are given a post to know the ability of critical thinking and learning outcomes. Hypothesis testing was done by Mancova test using SPSS 17.0 program. based on the Mancova test that has been done, obtained the significance of the critical thinking ability 0,00 and the learning result is also 0.00. Since all of the significance below 0.05 means there is an influence of the application of experimental methods using PhET simulations to critical thinking skills and student learning outcomes
\end{abstract}

Keywords: PhET simulations, critical thingking, learning outcome.

\begin{abstract}
Abstrak: Penelitian ini bertujuan untuk mengetahui pengaruh penerapkan metode eksperimen menggunakan simulasi PhET terhadap kemampuan berpikir kritis dan hasil belajar di tinjau dari pengetahuan awal siswa kelas VIII MTsN Maguwoharjo Sleman. Populasi yang digunakan adalah kelas VIII yang terbagi dalam 4 kelas parallel yaitu kelas VIII A, VIII B, VIII C, VIII D. Pengambilan sampel dilakukan secara acak, sehingga diperoleh kelas VIII B sebagai kelas control dan kelas VIII C sebagai kelas eksperimen yang diberi perlakuan dengan metode eksperimen menggunakan simulasi PhET. Teknik pengambilan data dilakukan dengan memberikan pretest untuk mengetahui pengetahuan awal siswa. Kemudian dilakukan pembelajaran yang berbeda, selanjutnya siswa diberi postest untuk mengetahui kemampuan berpikir kritis dan hasil belajarnya. Pengujian hipotesis dilakukan dengan uji Mancova dengan menggunakan program SPSS 17.0. berdasarkan uji Mancova yang telah dilakukan, diperoleh nilai signifikansi kemampuan berpikir kritis 0,00 dan hasil belajar juga 0,00 . Karena semua signifikansinya di bawah 0,05 berarti terdapat pengaruh penerapan metode eksperimen menggunakan simulasi PhET terhadap kemampuan berpikir kritis dan hasil belajar siswa.
\end{abstract}

Kata kunci: Simulasi PhET, berpikir kritis, hasil belajar.

\section{PENDAHULUAN}

Di zaman yang canggih dan modern seperti sekarang ini, teknologi informasi dan komunikasi dibutuhkan dalam setiap kehidupan. Perkembangan pesat dalam TIK telah mengubah gaya hidup pada saat ini. Penyebaran informasi dengan metode yang menerapkan teknologi seperti promosi, berita, pembelajaran, permainan dan lainnya dapat diakses melalui perangkat komputer dan smartphone. Pendidikan berbasis TIK merupakan sarana interaksi yang dapat dimanfaatkan oleh pendidik, tenaga kependidikan, dan peseta didik dalam meningkatkan efektifitas, kwalitas, produktivitas, serta akses pendidikan yang ada di Indonesia. Teknologi dan pengembangan ilmu pengetahuan berpengaruh pada peluang baru 
dalam strategi dan metode pembelajaran, termasuk pembelajaran sains di sekolah menengah (Sulisworo, 2014). Teknologi Informasi dan Komunikasi dapat menciptakan sebuah media pembelajaran, pada mulanya media hanya dianggap sebagai alat bantu mengajar guru (teaching aids). Alat bantu yang dipakai adalah alat bantu visual, misalnya gambar, model, object dan alat-alat lain yang dapat memberikan pengalaman konkret, motivasi belajar serta mempertinggi daya serap siswa.

Fisika merupakan ilmu fundamental karena merupakan tulang punggung bagi perkembangan ilmu pengetahuan dan teknologi (Nurhayati, dkk, 2014). Mata pelajaran fisika mulai diajarkan secara khusus kepada siswa semenjak sekolah menengah pertama (SMP). Menurut Astuti (2015) beberapa faktor yang mempengruhi keberhasilan siswa dalam belajar fisikia diantaranya faktor internal yang meliputi kemampuan awal, kebiasaan belajar, dapat berpikir kritis dan sebagainya. Kemampuan awal peserta didik penting untuk diketahui guru sebelum siswa memulai pembelajarannya, karena dengan demikian dapat diketahui apakah siswa telah mempunyai pengetahuan yang merupakan prasyarat untuk mengikuti pembelajaran sejauh mana siswa telah mengetahui materi apa yang akan disajikan.

Dari hasil observasi yang telah dilakukan oleh Prihatiningtyas (2013) dengan menggunakan angket kepada siswa kelas VIII bahwa sebanyak 64\% siswa mengatakan guru tidak memanfaatkan laboratorium dalam rangka proses belajar mengajar dan 62\% siswa mengatakan dalam satu semester guru mengajak melakukan praktikum kurang dari dua kali. Hal ini mengakibatkan keterampilan psikomotorik dan berpikir kritis siswa rendah karena jarang dilatihkan.

Guru lebih menitikberatkan pada pemberian materi tanpa ada praktikum sama sekali maupun menggunakan media pembelajaran. Dan juga dominasi guru dalam proses pembelajaran menyebabkan kecendrungan peserta didik lebih bersifat pasif, sehingga mereka lebih banyak menunggu sajian guru dari pada mencari dan menemukan sendiri pengetahuan, keterampilan atau sikap yang mereka butuhkan. Selain itu pembelajaran yang berpusat pada guru cenderung membiarkan peserta didik untuk bekerja secara sendiri-sendiri untuk mencapai tujuan pmbelajaran, ondisi ini mengakibatkan mata pelajaran fisika masih dipandang sebagai mata pelajaran yang sulit oleh para peserta didik sehingga hasil belajar peserta didik pun cenderung kurang baik (Muijs \& Reynolds, 2011).

Dalam banyak kasus, guru sains fokus pada konsep yang terkandung dalam buku. guru sains masih cenderung mempertahankan urutan dalam buku, terlepas dari kesesuaian lingkungan siswa (Sulisworo, 2014). Seharursnya guru dan media pembelajaran bisa di kombinasikan menjadi sarana pengajaran yang baik. Tidak harus menggunakan alat peraga ataupun harus ke laboratorium untuk melaksanakan pembelajaran fisika, tapi bisa menggunakan simulasi virtual dengan bantuan media pembelajaran seperti PhET simulation.

PhET adalah simulasi yang dibuat oleh University of Colorado yang berisi simulasi pembelajaran fisika, biologi, kimia untuk kepentingan pembelajaran dikelas atau belajar individu. Simulasi PhET menekankan hubungan antara fenomena kehidupan nyata dengan ilmu yang mendasari, mendukung pendekatan interaktif dan kontruktifis, memberikan umpan balik, dan menyediakan tempat kerja kreatif (Finkelstein, 2006).

Guru dapat menggunakan metode simulasi eksperimen dengan $\mathrm{PhET}$ online maupun offline yang diharapkan dapat membuat siswa lebih aktif belajar dan tidak hanya terpusat pada guru maupun media pembelajaran. Peran guru sangat penting dalam proses pembelajaran. Hal ini menuntut guru untuk menata kembali strategi pembelajaran dengan menggunakan alat peraga atau media pembelajaran kepada siswa.. Sebaik apapun kurikulum yang dikembangkan dan sarana yang disediakan, pada akhirnya guru juga yang melaksanakan 
dalam proses pembelajaran, oleh karena itu, banyak ahli menyebutkan bahwa guru merupakan faktor kunci dalam peningkatan mutu pendidikan.

Guru harus mempersiapkan dengan maksimal tentang materi yang akan disampaikan kepada siswa, selain itu juga harus bisa mengolah kelas sedemikian rupa sehingga tercipta interaksi antara siswa. Dengan demikian siswa juga dapat lebih mandiri dalam belajar dan menganalisa masalah yang ada pada suatu pembelajaran dan mampu berpikir lebih kritis dalam pembelajaran fisika agar hasil belajar siswa dapat lebih baik dari sebelumnya. Kemampuan berpikir kritis sangat penting untuk mengembangkan ilmu dan pengetahuan dan menjadikan siswa sebagai manusia yang unggul yaitu manusia yang cerdas, kritis dan kreatif. Kemampuan berfikir kritis juga akan berdampak dalam memecahkan masalah dan membuka wawasan pada pembelajaran yang diberikan sehingga juga akan berdampak pada hasil belajar siswa.

Hal yang dapat memperkuat pendahuluan ini bisa dilihat dari beberapa penelitian terdahulu yang relevan. Penelitian yang dilakukan oleh Kristina Gita Permatasari (2015) dengan judul "Penerapan Media Simulasi PhET (Physics Education Technology) Dalam Meningkatkan Minat Belajar dan Hasil Belajar Peserta Didik Pada Materi Pembelajaran Optika Geometri Dikelas X SMAN Bantul" memperoleh hasil perbedaan pembelajaran menggunakan simulasi PhET bila dibandingkan dengan pembelajaran konvensional dalam meningkatkan minat belajar dengan rata-rata kelas eksperimen (Simulation PhET) sebesar 96,03 sedangkan ratarata untuk kelas kontrol (konvensional) sebesar 89,65. Dan hasil belajar dengan rata-rata kelas eksperimen (Simulation PhET) sebesar 90,86 sedangkan rata-rata untuk kelas kontrol (konvensional) sebesar 86,55.

Penelitian yang dilakukan oleh Mutiara Dwi Cahyani (2013) dengan judul "Pengaruh Media Simulasi PhET Terhadap Peningkatan Prestasi Belajar Siswa Dalam Konsep Pembiasan Cahaya" memperoleh hasil perbandingan normalisasi antara kelompok eksperimen (0.74) dan kelompok control (0.56) menunjukan bahwa simulasi PhET lebih efektif dalam meningkatkan prestasi belajar siswa dalam konsep pembiasan cahaya. Dalam penelitian domain analisis (C4). Berdasarkan hasil dari kuisioner mengenai penggunaan media simulasi PhET dalam proses pembelajaran, disimpulkan bahwa siswa senang terhadap penggunaan simulasi PhET dalam pembelajaran.

Penelitian yang dilakukan oleh Iftikhatun Broroh (2011) dengan judul "Pengaruh Metode Eksperimen Nyata dan Maya Pada Simulasi PhET Terhadap Prestasi Belajar Fisika Tentang Mekanika Pokok Bahasan Elastisitas" memperoleh hasil skor pada saat pretest pada kelompok nyata, skor terendah adalah 2, skor tertinggi adalah 19 dan rata-rata sebesar 10,83. Pada posttest diperoleh skor terendah sebesar 6 dan skor tertinggi sebesar 23 dan rata-rata sebesar 16,6. Sedangkan kelompok eksperimen maya dengan simulasi pada saat pretest didapat skor terendah sebesar 3, skor tertinggi sebesar 20 dan rata-rata 11,03. Pada posttest diperoleh skor terendah sebesar skor 4, skor tertinggi sebesar 21, dan rata-rata sebesar 13,96.

Penelitian yang dilakukan oleh Komyadi (2014) dengan judul "Penerapan Media Simulasi PhET (Physics Education Thecnology) Untuk Meningkatkan Aktivitas Siswa Pada Fase Pengumpulan Data Percobaan Dan Mengolah Serta Merumuskan Suatu Penejelasan Dalam Model Pembelajaran Inquiry Training Di SMAN 5 Takengon" diperoleh nilai rata-rata aktivitas siswa pada siklus I 66,38 dan pada siklus II 81,74 dengan N-gain 45,69\% (sedang). Nilai rata-rata keterampilan proses sains siswa (aspek psikomotor) pada siklus I adalah 66,18 dengan ketuntasan klasikal 36\% dan pada siklus II 77,77 dengan ketuntasan klasikal 92\% dengan N-gain 47,81\% (sedang). Nilai rata-rata keterampilan proses sains (aspek kognitif) siswa pada siklus I adalah 61,87 dengan ketuntasan klasikal $48 \%$, sedangkan pada siklus II 78,15 dan ketuntasan klasikal 88\% dengan N-gain 69\% (sedang). Hasil angket respon siswa 
terhadap pembelajaran pada siklus I positif dan pada siklus II sangat positif. Dengan demikian penerapan model pembelajaran inquiry training menggunakan media simulasi $\mathrm{PhET}$ dapat meningkatkan keterampilan proses sains (aspek psikomotor dan kognitif).

\section{METODE PENELITIAN}

Penelitian ini merupakan penelitian eksperimen semu, model desain penelititan ini adalah randomized control grup pre-test post-test design yaitu rancangan secara acak dengan tes awal dan tes akhir dengan kelompok kontrol.

Untuk menguji hipotesis penelitian dari data yang terkumpul di analisis dengan uji MANCOVA (Multivariate Analisis of Covariance). MANCOVA merupakan perpanjangan dari analisis metode kovarian (ANCOVA) yang digunakan untuk menyimpulkan pengaruh varibel independen terhadap variabel dependen (Maneesha, 2013). Sebelum melakukan uji hipotesis dilakukan uji prasyarat yaitu meliputi uji normalitas dan homogenitas.

\section{HASIL DAN PEMBAHASAN}

Penelitian ini mengukur 2 varibel yaitu kemampuan berpikir kritis dan hasil belajar yang di tinjau dari pengetahuan awal siswa kelas VIII MTsN 9 Maguwoharjo Sleman. Peningkatan varibael tersebut dapat dilihat dari analisis data yang telah dilakukan. Sebelum melakukan uji hipotesis Mancova, dilakukan uji prasyarat terlebih dahulu yaitu uji normalitas dan homogenitas. Dimana penelitian yang dilakukan ini memiliki distribusi normal yang dapat di lihat pada tabel 1, 2, 3, 4 .

Tabel 1. Pretest hasil belajar

\begin{tabular}{cccccc}
\hline \multirow{2}{*}{ Kelas } & \multicolumn{4}{c}{ Kolmogorov-Smirnov } & \multirow{2}{*}{ Distribusi } \\
\cline { 2 - 5 } & Statistic & $\mathbf{N}$ & Sig. & & \\
\hline Pretest Eksperimen & 0,807 & 32 & 0,532 & 0,05 & Normal \\
Pretest Kontrol & 0,812 & 32 & 0,524 & & Normal \\
\hline
\end{tabular}

Tabel 2. Posttest hasil belajar

\begin{tabular}{cccccc}
\hline \multirow{2}{*}{ Kelas } & \multicolumn{4}{c}{ Kolmogorov-Smirnov } & \multirow{2}{*}{ Distribusi } \\
\cline { 2 - 5 } & Statistic & $\mathbf{N}$ & Sig. & & \\
\hline Posttest Eksperimen & 0.709 & 32 & 0,697 & 0,05 & Normal \\
Posttest Kontrol & 0,712 & 32 & 0,691 & & Normal \\
\hline
\end{tabular}

Tabel 3. Pretest berpikir kritis

\begin{tabular}{cccccc}
\hline \multirow{2}{*}{ Kelas } & \multicolumn{4}{c}{ Kolmogorov-Smirnov } & \multirow{2}{*}{ Distribusi } \\
\cline { 2 - 5 } & Statistic & $\mathbf{N}$ & Sig. & & \\
\hline Pretest Eksperimen & 1,082 & 32 & 0,192 & \multirow{2}{*}{0,05} & Normal \\
Pretest Kontrol & 0,471 & 32 & 0,980 & & Normal \\
\hline
\end{tabular}

Tabel 4. Posttest berpikir kritis

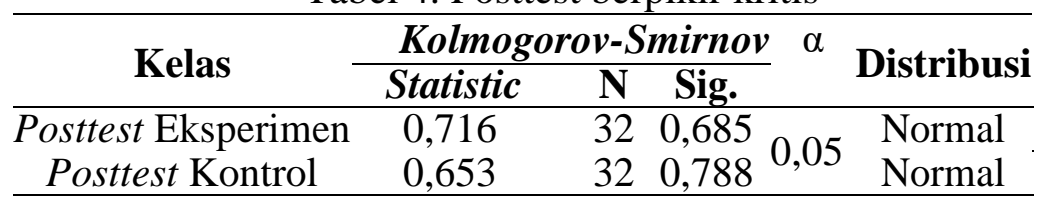

Untuk hasi uji homogenitas hasil belajar dan berpikir kritis didapat nilai signifikansi pretest dan postest di atas 0,05 yang artinya homogen. Setelah dilakukan uji normalitas dan homogenitas lalu dilakukan uji hipotesis yaitu uji mancova yang dapat dilihat dari tabel analisis menggunakan SPSS. 


\begin{tabular}{|c|c|c|c|c|c|c|c|c|}
\hline Source & $\begin{array}{l}\text { Dependent } \\
\text { Variable }\end{array}$ & $\begin{array}{l}\text { Type III Sum } \\
\text { of Squares }\end{array}$ & df & $\begin{array}{c}\text { Mean } \\
\text { Square }\end{array}$ & $\mathrm{F}$ & Sig. & $\begin{array}{l}\text { Noncent. } \\
\text { Parameter }\end{array}$ & $\begin{array}{c}\text { Observed } \\
\text { Power }^{2}\end{array}$ \\
\hline \multirow{2}{*}{$\begin{array}{l}\text { Corrected } \\
\text { Model }\end{array}$} & Posttest BK & $13236,715^{\mathrm{b}}$ & 3 & 4412,238 & 65,394 &, 000 & 196,183 & 1,000 \\
\hline & Posttest HB & $210,512^{\mathrm{c}}$ & 3 & 70,171 & 24,571 &, 000 & 73,714 & 1,000 \\
\hline \multirow[t]{2}{*}{ Intercept } & Posttest BK & 504,140 & 1 & 504,140 & 7,472 & ,008 & 7,472 & ,767 \\
\hline & Posttest HB & 38,019 & 1 & 38,019 & 13,313 & ,001 & 13,313 & ,948 \\
\hline \multirow[t]{2}{*}{ grup } & Posttest BK & 2903,526 & 1 & 2903,526 & 43,033 & ,000 & 43,033 & 1,000 \\
\hline & Posttest HB & 121,823 & 1 & 121,823 & 42,658 & ,000 & 42,658 & 1,000 \\
\hline \multirow[t]{2}{*}{ prehb15 } & Posttest BK & 34,161 & 1 & 34,161 &, 506 & ,479 &, 506 & ,108 \\
\hline & Posttest HB & 97,250 & 1 & 97,250 & 34,054 & ,000 & 34,054 & 1,000 \\
\hline \multirow[t]{2}{*}{ prebk39 } & Posttest BK & 9739,165 & 1 & 9739,165 & 144,345 &, 000 & 144,345 & 1,000 \\
\hline & Posttest HB &, 619 & 1 &, 619 &, 217 & ,643 &, 217 &, 074 \\
\hline \multirow[t]{2}{*}{ Error } & Posttest BK & 4048,285 & 60 & 67,471 & & & & \\
\hline & Posttest HB & 171,348 & 60 & 2,856 & & & & \\
\hline \multirow[t]{2}{*}{ Total } & Posttest BK & 578286,000 & 64 & & & & & \\
\hline & Posttest HB & 7375,000 & 64 & & & & & \\
\hline \multirow{2}{*}{$\begin{array}{l}\text { Corrected } \\
\text { Total }\end{array}$} & Posttest BK & 17285,000 & 63 & & & & & \\
\hline & Posttest HB & 381,859 & 63 & & & & & \\
\hline
\end{tabular}

Dari olah data SPSS dapat di katakan bahwa terdapat pengaruh penerapan metode eksperimen menggunakan simulasi PhET terhadap kemampuan berpikir kritis dan hasil belajar siswa di tinjau dari pengetahuan awal siswa kelas VIII MTsN 9 Maguwoharjo Sleman.

\section{KESIMPULAN}

a) Terdapat perbedaan pengaruh pembelajaran menggunakan metode eksperimen dengan PhET simulasi bila dibandingkan dengan pembelajaran dengan metode konvensional terhadap kemampuan berpikir kritis siswa kelas VIII MTsN 9 Maguwoharjo Sleman.

b) Terdapat perbedaan pengaruh pembelajaran menggunakan metode eksperimen dengan PhET simulasi bila dibandingkan dengan pembelajaran dengan metode konvensional terhadap kemampuan hasil belajar siswa kelas VIII MTsN 9 Maguwoharjo Sleman.

c) Terdapat pengaruh penerapan metode eksperimen terhadap kemampuan berpikir kritis dan hasil belajar siswa yang ditinjau dari pengetahuan awal siswa (prediktor).

\section{SARAN}

a) Untuk penelitian yang sejenis dapat dikembangkan pada aspek lain, misalnya pada ranah afektif dari aspek psikomotor.

b) Pembelajaran menggunakan PhET dapat digunakan pada materi fisika yang relevan.

c) Untuk penelitian selanjutnya lebih baik jika guru dan siswa dapat lebih piawai dan kreatif dalam menguasai cara-cara menggunakan PhET sehingga bias menciptakan suasana kelas yang lebih aktif dan menyenangkan.

\section{DAFTAR PUSTAKA}

Aningtyas, Prih. 2015. Implementasi Simulasi PhET dan Kit Sederhana untuk Mengajarkan Keterampilan Psikomotor Siswa Pada Pokok Bahasan Optik. Jurnal Pendidikan IPA Indonesia, Vol. 18, No.22.

Ardiyanti, Farida dan Winarti.2013. Pengaruh Model Pembelajaran Berbasi Fenomena untuk Meningkatkan Keterampilan Berpikir Kritis Siswa Sekolah Dasar. Jurnal Kaunia. Vol. IX, NO.2: 27-33. 
Arikunto, Suharsimi. 2012. Dasar-Dasar Evaluasi Pendidikan Edisi 2. Jakarta: Bumi Aksara.

Astuti, Siwi Puji.2015. Pengaruh Kemampuan Awal dan Minat Belajar Terhadap Prestasi Belajar Siswa. Jurnal Formatif 5(1): 68-75. ISSN: 2088-351X.

Demirci. 2005. A Study About Students Misconceptions In Force and Motion Conceps By Incorporating A Web-Assisted Physics Program. The Turkish Online Jpurnal of Educational Technology. Vol. 4(3).

Dimyati dan Mudjiono. 2015. Belajar dan Pembelajaran. Jakarta: Rineka Cipta

Finkelstein, N. 2006. "Hightech Tools For Teaching Physics:The Physics Education Technology Project". Merlot journal of online learning and teaching. Vol. 2 (3): 110-121.

http://rachmadresmi.blogspot.co.id/2009/03/phet-simulasi-fisika-untuk-membantu.html (di akses pada tanggal 13 april 2017 jam 10)

Ismaimuza, Dasa. 2011. Kemampuan Berfikir Kritis Matematis Ditinjau dari Pengetahuan Awal Siswa. Jurnal Pendidikan Matematika. Vol.2 No 1.

K.Perkins, W. Adams, M. Dubson, N. Finkelstein, S. Reid, and C. Wieman. 2006. "PhET: Interactive simulations for Teaching and Learning Physics". The Physics Teacher. Vol. 44.

Maneesha, dkk. 2013. Multiple Regression Analysis Using ANCOVA in Univesity Model. International Journal of Applied Physics and Mathematics. Vol.3, No.5.

Muijs \& Reynoalds. 2011. Efektif Teaching, Teori dan Aplikasi. Yogyakarta: Pustaka Pelajar.

N. D. Finkelstein, W.K.Adam, C.J. Keller, P.B.Kohl, N.S. Podolefsky, and S. Reid. 2005. When learning about the real world is better done virtually: A Study of substituting computer simulation for laboratory equipment. Physical Review Special TopicsPhysics Education Research.

N.D. Finkelstein, K.K. Perkins, W. Adams, P. Kohl, and N. Podolefsky. 2004. Can Computer Replace Real Equipment in Undergraduate Laboratories?. Physics Education Research Conference Proceedings.

Nurhayati, dkk. 2014. Penerapan Metode Demonstrasi Berbantu Media Animasi Software PhET Terhadap Hasil Belajar Siswa Dalam Materi Listrik Dinamis Kelas X Madrasah Aliyah Negeri Pontianak. Jurnal Pendidikan Fisika dan Aplikasinya. Vol 4. No 2.

Rofiah, Emi dkk. 2013. Penyususnan Instrumen Tes Kemampuan Berpikir Tingkat Tinggi Fisika pada Siswa SMP. Jurnal Pendidikan Fisika. Vol 1. No 2.

Sabri, Ahmad. 2005. Strategi Belajar Mengajar. Jakarta: Quantum Teaching.

Sadiman, Arief S. 2012. Media Pendidikan. Jakarta: RajaGrafindo Persada.

Sangrà, A., \& González-Sanmamed, M. (2010). The role of information and communication technologies in improving teaching and learning processes in primary and secondary schools. ALT-J Research in Learning Technology. Vol 18. No 3: 207-220.

Sari, DP, dkk. 2013. Uji COba Pembelajaran IPA Dengan LKS Sebagai Penunjang Media Virtual PhET Untuk Melatih Keterampilan Proses Pada Materi Hukum Archimedes. Jurnal Pendidikan Sains. Vol 01. No 02. 
Sudjana, Nana dan Ahmad Rivai. 2010. Media Pengajaran. Bandung: Sinar Bara Algesindo.

Sudjana, Nana, 2005. Dasar-Dasar Proses Belajar Mengajar. Bandung: SInar Baru Algensindo

Sugihartono, dkk. 2007. Psikologi Pendidikan. Yogyakarta: UNY Pers

Sulisworo, Dwi. 2014. The Effect of Cooperative Learning, Motivation and Information Technology Literacy to Achievment. International Journal of Learning \& Development. ISSN 2164-4063. Vol. 4, No. 2.

Suryabrata, Sumadi, 2012. Psikologi Pendidikan. Jakarta: Rajawali Pers.

Susanto, Ahmad. 2014. Teori Beajar dan Pembelajaran di Sekolah Dasar. Jakarta: Kencana.

Sutopo, Ariesto Hadi. 2011. Teknologi Informasi dan Komunikasi Dalam Pendidikan. Jakarta: Graha Ilmu.

Uno, Hamzah B. 2009. Model Pembelajaran Menciptakan Proses Belajar Mengajar yang Kreatif dan Efektif. Jakarta: PT Bumi Aksara. 